\title{
The Phonological Process of Regressive and Progressive Assimilations on the Lyrics of the Rap Song, "Rap God" by Eminem
}

\author{
Hendar, Yunada Satria \\ English Department, Widyatama University,Bandung, Indonesia \\ h.hendar@widyatama.ac.id \\ yunanda.satria@widyatama.ac.id
}

\begin{abstract}
Rapping as one of the musical genres essentially involves the speaking or chanting of rhyming lyrics, often set to a beat. The rhyming created by rappers is considered to be one of the most sophisticated styles of poetry. Themes often address provocative subjects such as violence, sex and socio-political issues. Rapping which first gained popularity in the U.S in the 1970s as a kind of street act especially among African-American teenagers now becomes very famous musical genre in the world. The main objectives of this descriptive qualitative research are to find out how the processes of regressive and progressive assimilation are taken place when a very well known rap singer, Eminem, is singing his famous song Rap God in his single album and to find out the determinant factor how they happen in terms of place and manner of articulations and voicing. Regressive assimilation happens when the following sound in a word influences the preceding sound as in light blue /lait blu:/ pronounced rapidly as /laip blu:/ whereas progressive assimilation happens when the preceding sound influences the following sound since the preceding sound is too dominant such as in the / in $\underline{\jmath}$ / which turns to be /in $\underline{n}$ /. The result of the research show that based on the data found in the song, there are 21 data of phonological processes of regressive assimilation and 14 data of phonological processes of regressive assimilation and the factors such as place and manner of articulation as well as voicing play very important part in assimilation process.
\end{abstract}

Keywords: rapping, genre, regressive and progressive assimilation, place of articulation

\section{INTRODUCTION}

Rapping which first gained popularity in the U.S in the 1970s as a kind of street act especially among African-American teenagers now becomes very famous musical genre in the world. This kind of musical genre also known as hip hop has a very specific characteristic as it fuses the rhythm-based lyricism of hip hop music with pop music's preference for melodious vocals and catchy tunes (http://www.plasticlittleraps.com). The rhyming created by rappers is considered to be one of the most sophisticated styles of poetry and the lyrics

The lyrics of rap music as a part of hip-hop life style often address provocative subjects such as violence, sex, rebellion and socio-political issues. Some famous rappers who has released some best seller album are Ice Cube, Drake, Snoop Dogg, 50 Cent, Tupac Shakur, and Eminem.

Regarding the speaking or chanting of rhyming lyrics, often set to a beat, the main objectives of this descriptive qualitative research are 1) to find out regressive and progressive assimilations taken place to the song Rap God sung by Eminem. Roach (1998) and Spencer (1996) argue that when we find a phoneme realized differently as a result of being near some other phoneme belonging to a neighbouring word, we call this an instance of assimilation. He further explains that generally speaking, the cases that have most often been described are assimilation affecting consonants

There are two types of assimilation in English, namely regressive and progressive assimilations. Both, however, refers to the change of phoneme, a basic unit of a language's phonology, which is combined with other phonemes to form meaningful units such as words or morphemes (Gimson, 2008:41). The former deals with the phoneme of final consonant $(\mathrm{Cf})$ of a word which changes to become like initial consonant $(\mathrm{Ci})$ of its neighbouring word in some way in other words, the phoneme that comes first is affected by the one that comes after it as in the following words.

\section{Love me /l v mi:/ $\rightarrow$ /l $\underline{\mathbf{m}} \underline{\text { mi }}: /$}

Whereas the latter occurs if initial consonant $(\mathrm{Ci})$ changes to become final consonant (Cf) as seen in the words below: Read These /ri: $\underline{\mathrm{d}} \underline{\mathrm{di}} \mathrm{z} / \rightarrow / \mathrm{ri}: \underline{\mathrm{d}} \underline{\mathrm{di}}: \mathrm{z} /$

2) to find out how the assimilations happen viewed from the place and manner of articulations and voicing

\section{METHOD}

The main data of this descriptive research is taken from the rap song 'Rap God' sung by an American rapper, Eminem. The song released on October $15^{\text {th }}, 2013$ deals with the problems faced by Eminem in his career and it has 202 sentences or 1.560 words as recorded by Guinness World 
Record. The procedures of how to get the data needed for this research are transcribing the lyrics of the song, analyzing the assimilation occurred when it is sung by the rapper, classifying the kinds of assimilation; regressive or progressive assimilation, analyzing how assimilation happens based on the place and manner of articulation and voicing and drawing conclusion.

\section{RESULT DISCUSSION}

Based on the analyzed data taken mainly from the lyrics of the song, Rap God sung by a very well-known American rapper, Aminem, and regarding the first objective of this research, it was obtained that there were 35 data on assimilation and 21 data $(60 \%)$ of the assimilation data obtained belong to regressive assimilation, the phoneme of final consonant $(\mathrm{Cf})$ of a word which changes to become like initial consonant $(\mathrm{Ci})$ of its neighbouring word (Spencer, 1996) as seen on table 1 below:

Table 1: Regressive Assimilation

\begin{tabular}{|c|c|c|}
\hline Data Code & Sentence & $\begin{array}{l}\text { Regressive } \\
\text { Assimilation } \\
\end{array}$ \\
\hline D1/L17/R & $\begin{array}{l}\text { But for me to rap like a } \\
\text { computer must be in } \mathbf{m y} \\
\text { genes }\end{array}$ & $\begin{array}{l}/ \underline{\mathrm{In}} \underline{\mathrm{maI}} / \mathrm{maI} \\
\underline{\underline{\mathrm{ma}}}\end{array}$ \\
\hline D2/L28/R & $\begin{array}{l}\text { You don't really wanna } \\
\text { get into a pissing match }\end{array}$ & $\begin{array}{l}\text { /pisin mæt / } \rightarrow \\
\text { /pisım mæt / }\end{array}$ \\
\hline D3/L22/R & $\begin{array}{l}\text { Ever since Bill Clinton } \\
\text { was still in office }\end{array}$ & $\begin{array}{l}/ \mathrm{W} \quad \underline{\mathrm{z}} \underline{\mathrm{s} t \mathrm{Il} /} / \\
/ \mathrm{W} \underline{\mathrm{s}} \underline{\mathrm{s} t \mathrm{I}} / /\end{array}$ \\
\hline $\mathrm{D} 4 / \mathrm{L}$ & $\begin{array}{l}\text { I was signed to Aftermath } \\
\text { after the fact }\end{array}$ & $\begin{array}{l}/ \mathrm{w} \underline{\mathrm{z}} \text { saind/ } \rightarrow \\
/ \mathrm{w} \underline{\mathrm{s}} \text { saind/ }\end{array}$ \\
\hline D5/L38/R & How could I not blow? & $\begin{array}{l}/ \mathrm{n} \underline{\mathrm{t}} \underline{\mathrm{b}} \mathrm{l} / \\
/ \mathrm{n} \underline{\mathrm{p}} \underline{\mathrm{b}} /\end{array}$ \\
\hline D6/L47/R & $\begin{array}{l}\text { Let me show you } \\
\text { maintaining this shit ain't } \\
\text { that hard, that hard }\end{array}$ & $\begin{array}{l}/ \mathrm{let} \underline{\mathrm{mi}} / \rightarrow / \mathrm{lem} \\
\underline{\mathrm{mi}} /\end{array}$ \\
\hline D7/L54/R & $\begin{array}{l}\text { and did nothing but shoot } \\
\text { for the moon since }\end{array}$ & $\begin{array}{l}/ \mathrm{n} \theta \mathrm{I} \underline{\mathrm{b}} \underline{\mathrm{b}} \mathrm{t} / \mathrm{l} \\
/ \mathrm{n} \theta_{\mathrm{Im}} \underline{\mathrm{b}} \mathrm{t} /\end{array}$ \\
\hline $\mathrm{D} 8 / \mathrm{L} 55 / \mathrm{R}$ & $\begin{array}{l}\text { MC's get taken to school } \\
\text { with this music }\end{array}$ & 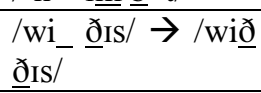 \\
\hline D9/L62/R & $\begin{array}{l}\overline{\text { Blow up and being in } a} \\
\text { position }\end{array}$ & $\begin{array}{l}/ æ \underline{\text { d }} \text { bi in/ } \\
/ \text { be } \text { bi In/ }\end{array}$ \\
\hline D10/L73/R & Little gay looking boy & $\begin{array}{l}\text { /loking boil/ } \\
\text { /lvkim boil }\end{array}$ \\
\hline D11/L74/R & $\begin{array}{l}\text { So gay I can barely say it } \\
\text { with a 'straight' face } \\
\text { looking boy }\end{array}$ & $\begin{array}{l}/ \mathrm{kæn} \text { beali/ } \rightarrow \\
/ \mathrm{kæw} \text { beali/ }\end{array}$ \\
\hline
\end{tabular}

Table 1, Cont.

\begin{tabular}{|c|c|}
\hline D12/L97/R & $\begin{array}{l}/ \mathrm{n} \underline{\mathrm{t}} \text { bi } / \rightarrow / \mathrm{np} \\
\underline{\mathrm{bi}} / /\end{array}$ \\
\hline D13/L102/R & $\begin{array}{lll}\text { We have nothing in } / \mathrm{k} \mathrm{m} \underline{\mathrm{n}} \mathrm{pu} \mathrm{dl} / \\
\text { common, poodle } & \rightarrow / \mathrm{m} \mathrm{m} \underline{\mathrm{m}} \\
& \mathrm{pu} \mathrm{dl} /\end{array}$ \\
\hline D14/L113/R & $\begin{array}{ll}\text { Just in case 'cause even } & \text { /In } \\
\text { you unsigned } & \text { keIs/ }\end{array} \rightarrow$ /In \\
\hline D15/L150/R & $\begin{array}{lll}\text { I'm devastating more } & \text { I'devəsteitin } \underline{\mathrm{m}} / \\
\text { than } & \text { ever } & \rightarrow \text { /'devəsteItI } \underline{\mathrm{m}} \\
\text { demonstrating } & \underline{\mathrm{m}} /\end{array}$ \\
\hline $\begin{array}{l}\text { D16 } \\
\text { /L155/R }\end{array}$ & $\begin{array}{l}\text { /'eliveitın } \\
\text { mju zik/ } \\
\text { /'eliveitım } \\
\text { mju zik/ }\end{array}$ \\
\hline $\begin{array}{l}\text { D17 } \\
\text { /L173/R }\end{array}$ & 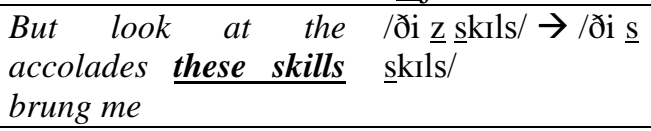 \\
\hline $\begin{array}{l}\text { D18 } \\
\text { /L173/R }\end{array}$ & 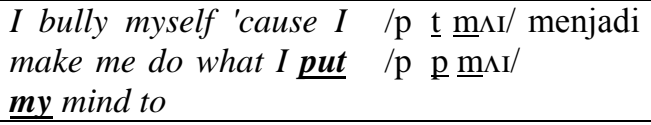 \\
\hline $\begin{array}{l}\text { D19 } \\
\text { /L185/R }\end{array}$ & $\begin{array}{lll}\text { Angels fight with devils } & \begin{array}{l}\text { /WI } \underline{\theta} \\
\text { /WI }\end{array} \text { devls/ } & \text { devls/ }\end{array} \quad \rightarrow$ \\
\hline $\begin{array}{l}\text { D } \\
\text { 20/L189/R }\end{array}$ & $\begin{array}{l}\text { Then you may be a lænd } \underline{\mathrm{m}} / \rightarrow / æ \underline{m} \\
\text { little patient and more } \underline{\mathrm{m}} / \\
\text { sympathetic to the } \\
\text { situation }\end{array}$ \\
\hline $\begin{array}{l}\text { D } \\
\text { 21/L194/R }\end{array}$ & 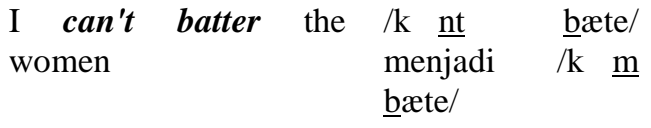 \\
\hline
\end{tabular}

Meanwhile 14 data (40\%) of the assimilation data obtained belong to progressive assimilation, it happens due to the fact that the phoneme of initial consonant $(\mathrm{Ci})$ of neighboring word changes to become final consonant $(\mathrm{Cf})$ of the previous word as seen in the following table 2 .

Tabel 2: Progressive Assimilation

\begin{tabular}{|c|c|c|}
\hline $\begin{array}{l}\text { Data } \\
\text { Code }\end{array}$ & Sentence & $\begin{array}{l}\text { Progressive } \\
\text { Assimilation }\end{array}$ \\
\hline D1/L1/P & $\begin{array}{l}\text { I'm beginning to feel like } \\
\text { a Rap God }\end{array}$ & $\begin{array}{l}/ \text { bi'ginin } \underline{\text { tu }} / \rightarrow \\
/ \text { bI'ginin } \underline{\text { nu }} /\end{array}$ \\
\hline D2/L26/P & $\begin{array}{l}\text { Syllables, skill-a-holic } \\
\text { (kill them all with) }\end{array}$ & $\begin{array}{l}/ \mathrm{kIl} \text { ðem/ } \rightarrow / \mathrm{kIl} \\
\mathrm{lem} /\end{array}$ \\
\hline D3/L47/P & $\begin{array}{l}\text { Let me show you } \\
\text { maintaining this shit } \\
\text { ain't that hard, that hard }\end{array}$ &  \\
\hline
\end{tabular}


Table 2, Cont.

\begin{tabular}{|c|c|}
\hline D4/L53/P & $\begin{array}{l}\text { Hit the earth like an } / \mathrm{hIt} \underline{\mathrm{d}} \mathrm{I} / \rightarrow / \mathrm{h} \mathrm{t} \underline{\mathrm{t}} \mathrm{\textrm {t }} / \\
\text { asteroid }\end{array}$ \\
\hline D5/L55/P & $\begin{array}{lll}\begin{array}{l}\text { MC's get taken to school } \\
\text { with this music }\end{array} & \text { /terkon tun tu:/ } & \rightarrow \\
& \text { /terkon nu:/ } & \end{array}$ \\
\hline D6/L65/P & 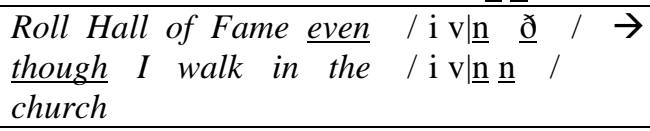 \\
\hline D7/L68/P & $/ \underline{\mathrm{n}} / \mathrm{\partial} / \rightarrow / \underline{\mathrm{n}}$ \\
\hline D8/L92/P & 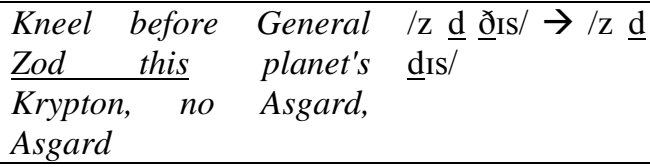 \\
\hline D9/L125/P & 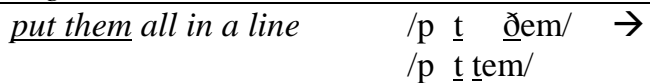 \\
\hline $\mathrm{D} 10 / \mathrm{L} 154 / \mathrm{P}$ & $\begin{array}{lll}\begin{array}{l}\text { Cause I know the way to } \\
\text { get them motivated }\end{array} & \text { tem } \mathrm{t} \text { tem } / \rightarrow / \text { t }\end{array}$ \\
\hline D11/L186/P & $\begin{array}{l}\text { Here's what they want } / \mathrm{w} \text { t } \underline{\mathrm{t}} \mathrm{e} / \rightarrow / \mathrm{w} \underline{\mathrm{t}} \\
\text { from me }\end{array}$ \\
\hline D12/L190/P & 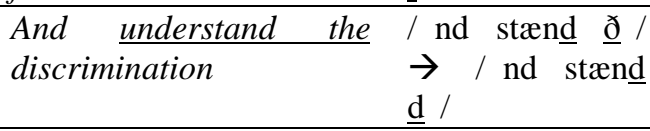 \\
\hline D13/L193/P & $\begin{array}{l}\text { /lemə' neId } \text { den/ } \\
\rightarrow \quad / \text { lemə' neId } \\
\text { den/ }\end{array}$ \\
\hline D14/L195/P &  \\
\hline
\end{tabular}

Since the assimilation process occurs to consonants as Roach (1998) states that generally speaking, the cases that have most often been described are assimilation affecting consonant, there are three elements which cannot be apart from assimilation process and how to produce consonant sounds. Those are place of articulation, manner of articulation and voicing. Place of articulation deals with the location at which two speech organs such as lower and upper, lower and upper lips, tongue, hard and soft palate etc., approach or come together in producing a speech sound; whereas manner of articulation concerns with the degree of obstruction or the type of channel imposed upon the passage of air at a given place of articulation, as denoted by such categories as stop (plosive), fricative, affricate, nasal, lateral and approximant (semivowel) (http://www.dictionary.com) and voicing deals with Sounds which can be voiced or voiceless. Voiced phonemes engage the vocal chords. Voiceless phonemes don't engage the vocal chords.

Here are the sample data analysis based on the three factors on which the classification of consonant sound is based

\section{Regressive assimilation}

Data 1

......But for me to rap like a computer must be in my genes (D1/L17/R)
The word in my /프 mai/ becomes Im mai/ when they are pronounced in a rapid way by a rapper. It means $\mathrm{Cf}$ in one word changes to become like $\mathrm{Ci}$ of its neighbouring word. It is called as regressive assimilation. Based on the analysis of place articulation, phoneme $/ \mathrm{n} /$ which belongs to alveolar sound becomes $/ \mathrm{m} /$, bilabial sound and in terms of manner of articulation, they belong to the same classification, namely nasal sounds and seen from the voicing point of view, they belong to voiced sounds.

\section{Progressive assimilation \\ Data 1 \\ ... I'm beginning to feel like a Rap God (D1/L1/P)}

From the data 1 taken from regressive assimilation, it can be explained that assimilation happens to the underlined word, beginning to / bi'ginı tu / which turns tobe /bi'ginin nu / when those words are pronounced in a rapid way by a rapper. The phoneme /t/ $(\mathrm{Ci})$ changes to become like phoneme /n/ (Cf). It means the progressive assimilation occurs. Based on the analysis of place of articulation, it can be explained that phoneme $/ \mathrm{t} /$ turns to become $/ \mathrm{n} / \mathrm{not} / \mathrm{n} /$ as they both belong to alveolar sounds. Viewed from manner of articulation, phoneme /n/ and / $\mathrm{g} /$ have the same characteristics, that is nasal sound and analyzed from voicing, they belong to voiced sounds. The following table 3 can expectedly facilitate us to know the classification of consonants.

Tabel 3: Place and manner of articulation

\begin{tabular}{|c|c|c|c|c|c|c|c|c|c|}
\hline & & $\begin{array}{l}\text { Pleckismi: } \\
\text { Wlihal }\end{array}$ & 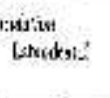 & Dasit & inteds & 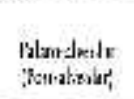 & Bix: 't & thit & Cutal \\
\hline & Xies: & 00 & & & 11 & & & 10 & \\
\hline & tikx": & & $\mathrm{F}$. & : 6 & $s:$ & $\therefore$ & & & h \\
\hline & Nitis: & & & & & af its & & & \\
\hline & Sasi & $n$ & & 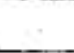 & 1 &  & & $\pi$ & \\
\hline & Line! & & & & 1 & & & & \\
\hline & Aprisitan & " & . & & & r & 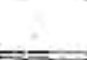 & & \\
\hline
\end{tabular}

(Roach, 1998:62)

From the data analyzed, it can be obtained that instead of rapid pronunciation of the rapper, either regressive or progressive assimilations takes place due to the similarity of the consonant sound classification which are grouped into place of articulation, manner of articulation and voicing.

\section{CONCLUSION}

Based on the data analyzed taken from the rap song called Rap God sung by a famous American rapper, Eminem, it can be concluded that assimilations consisting of 21 data $(60 \%)$ of regressive assimilation and 14 data $(40 \%)$ of progressive assimilation are found in the song. Since assimilation is related much to consonant sounds, it can be a part of three factors determining classification of consonant sounds, namely the place of articulation, manner of articulation and 
voicing. In other words, the changing phonemes as they are influenced by initial or final consonant of other words well known as assimilation must be in line with the three elements as explained earlier.

\section{REFERENCES}

Gimson, A.C. (2008). Crutenden, A., ed., The Ponunciation of English (7 ed.), Hodder.

Roach, Peter. (1998). English Phonetics and Phonology. Cambridge: Cambridge University Press.

Spencer, A. (1996). Phonology: Theory and Description. Oxford and Cambridge, Mass. Balckwell Publishers.

http://www.plasticlittleraps.com/history-of-rap-music.html $(15 / 7 / 16)$

http://www.dictionary.com. Place of articulation and manner of articulation (24/9/16) 